\title{
CARDIOVASCULAR DISEASE AMONG PATIENTS WITH TYPE 2 DIABETES: ROLE OF HOMOCYSTEINE AS AN INFLAMMATORY MARKER
}

\author{
*ASHOK SAHU ${ }^{1,2}$, TRAPTI GUPTA², ARVIND KAVISHWAR ${ }^{3}$, R. K. SINGH \\ ${ }^{1}$ MGM Medical College Indore, Jabalpur, India; \\ *e-mail: asahu888@gmail.com; asahu888@yahoo.co.in; \\ ${ }^{2}$ NSCB Medical College, Jabalpur, India; \\ ${ }^{3}$ Regional Malaria Research Centre of Tribal (ICMR), Jabalpur, India; \\ ${ }^{4}$ Chirayu Hospital, Bhopal, India
}

\begin{abstract}
It is known that inflammation has a role in the pathogenesis of cardiovascular diseases; measurement of inflammatory markers improves the risk prediction of cardiovascular diseases. Hyperhomocysteinemia has been correlated with the occurrence of blood clots, heart attacks and strokes; though it is unclear whether hyperhomocysteinemia is an independent risk factor for these conditions. In the present study, we aimed to evaluate the role of homocysteine in type 2 diabetes patients with cardiovascular disease in a population of Madhya Pradesh India. Total 100 type 2 diabetes patients were included in the study, of these 50 had angiographically proven cardiovascular disease and 50 had no evidence of it. High sensitivity C-reactive protein, fibrinogen, and lipoprotein (a) were measured in serum. Homocysteine, blood glucose in plasma, erythrocyte sedimentation rate, glycated haemoglobin were measured in whole blood. A albumin excretion rate, creatinine clearance rate were measured in the urine sample for renal function. It was shown that, levels of homocysteine and other inflammatory markers were elevated significantly in the group II $(n=50)$. A correlation between hyperhomocysteinemia and inflammatory markers in patients with impaired renal function was observed. It was concluded that impairment of renal function is a key factor that affects homocysteine level.
\end{abstract}

Key words: homocysteine, high sensitivity C-reactive protein, lipoprotein (a), creatinine clearance rate, cardiovascular disease, type 2 diabetes, glycated haemoglobin.

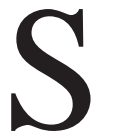

everal novel risk factors like interleukin-6, tumor necrosis factor, $\mathrm{N}$ type brain natriuretic peptide (NTproBNP) have been proposed as potential criteria for improved detection of subclinical cardiovascular disease [1-3]. In particular, clinical interest has focused on emerging lipid parameters such as lipoprotein(a), on inflammatory markers such as high sensitivity C-reactive protein, fibrinogen, erythrocyte sedimentation rate and homocysteine $[1,4,5]$. Direct comparisons of the magnitude of predictive value associated with each of these parameters have been rare.

Cardiovascular disease (CVD) is considered to be an inflammatory process triggered in response to injury. The increase in inflammatory markers was shown to be related to the risk of cardiovascular disease in diabetic subjects [6,7].

Several studies demonstrated that plasma homocysteine levels were elevated in diabetes patients
[8-10] but the role of inflammatory activity is not well established, the most probable mechanism by which homocysteine induces vascular problem is an alteration of endothelial functions by induction of oxidative stress [11], impaired generation of nitric oxide (NO) [12], decreased vasodilatation, increased proliferation of smooth muscles [13], decreased anticoagulant with suppression of thrombomodulation in endothelial cells [14] and lipid peroxidation [15].

In studies hyperhomocysteinemia is reported as a risk factor for increased risk of CVD in Indians $[16,17]$. However, the results of hyperhomocysteinemia in CVD were been conflicting as several other studies had failed to demonstrate an association between homocysteine and CVD in Indians $[18,19]$. Therefore, this study was done to evaluate the relationship between the homocysteine levels and CVD in our population. 
The present study was undertaken to compare plasma inflammation markers and homocysteine levels in diabetic patients with cardiovascular disease and to investigate possible relationship between inflammatory activity and homocysteine levels in them.

\section{Materials and Methods}

The study was a case-controlled in design; we have selected patients as they were presented. The patients included in the present study were all admitted to the intensive coronary care unit (ICCU) or attending the outpatient department of medicine, MGM Medical College and Hospital Indore. Informed consent was obtained from all individual participants included in the study. The Institutional ethical committees of Devi Ahilya Vishwavidyalaya vide their order no. No.Acdm/XI/PhD/Medical Biochemistry/07/496 of DAVV year April 2007 has accorded their approval for the PhD thesis work on the topic entitled "The emerging Role of Novel Markers in Coronary Atherosclerostic Patients with Type-II DM" and the present article is an outcome of the said PhD work.

Consecutive 100 patients undergoing coronary angiography suffering from type 2 diabetes, at our hospital over a period of two years were included in the study. The diagnosis of CVD was made on the basis of clinical history and 12 - lead standard electrocardiogram (ECG) before subjecting them to coronary angiography. The presence of any diameter stenosis $\geq 30 \%$ according to coronary angiography using a standard Judkin technique by visual assessment of coronary artery were included in the study as patients ( $n=50$, group II) 45 of them were male and 5 were female, the mean age was observed at (61.32 \pm 10.19$)$ and others were excluded and there are no dropouts.

Age and sex matched 50 diabetic subjects as a control (Group I) from medicine outpatient department (OPD) and blood bank with no history of CVD or had normal ECG, were selected for the study. Control had 40 male and 10 female subjects with mean age $52.02 \pm 9.47$. The name, age, sex, occupation and clinical history were taken on pro forma. Previous histories of diabetes, smoking, hypertension were noted. Fully informed consent was obtained from patients and controls of both groups $(n=100)$.

Exclusion criteria included the use of aspirin, S-adenosylmethionine, vitamin supplements, alcohol, anticonvulsant, estrogens, lipid lowering ther- apy, other infectious diseases and medications that might affect high sensitivity C-reactive protein (hsCRP), lipoprotein (Lp(a)) and homocysteine metabolism.

Blood specimens were drawn at 8:00 am after an overnight fast. Samples were centrifuged within $2 \mathrm{~h}$ of collection, plasma and serum were separated and frozen immediately at $-20^{\circ} \mathrm{C}$ [20].

In our study smoking was defined as a regular smoking of cigarettes/beedies [21]. Body mass index (BMI) calculated $\left(\mathrm{kg} / \mathrm{m}^{2}\right)$, patients whose body mass index is $\geq 25 \mathrm{~kg} / \mathrm{m}^{2}$, were considered as obese [22]. Blood pressure measured by the person in the sitting position after 5 min rest. A participant was defined as having hypertension if systolic blood pressure was $160 \mathrm{mmHg}$ or more, if the diastolic blood pressure was $95 \mathrm{mmHg}$ or more or if the participant was receiving drug treatment for hypertension [23]. Diabetes mellitus was considered present in patients with a known history of diabetes and in patients with fasting glucose $\geq 126 \mathrm{mg} / \mathrm{dl}(7.0 \mathrm{mmol} / \mathrm{l}) \mathrm{ac}-$ cording to the World Health Organization (WHO) criteria [24]. A positive family history of CVD was defined as first-degree relative that had documented CVD $<55$ years in males or $<65$ years in females. For lipid analysis, samples were obtained after an overnight fast. Patients who had a serum concentration of total cholesterol (TC) $\geq 240 \mathrm{mg} / \mathrm{dl}$, or triglyceride (TG) $\geq 300 \mathrm{mg} / \mathrm{dl}$, or low-density lipoprotein cholesterol (LDL-C) $\geq 160 \mathrm{mg} / \mathrm{dl}$ or high-density lipoprotein cholesterol (HDL-C) $\leq 40.0 \mathrm{mg} / \mathrm{dl}$ or very-lowdensity lipoprotein cholesterol (VLDL-C) $\geq 40.0$ are considered as hyperlipedemics [25]. Homocysteine, high sensitivity C-reactive protein, lipoprotein (a) levels $\geq 15.0 \mathrm{mg} / \mathrm{dl}, \geq 1.5 \mathrm{mg} / \mathrm{dl}, \geq 30 \mathrm{mg} / \mathrm{dl}$ were considered as higher or increased risk, respectively [26-28].

For the assessment of each parameter we used the commercially available analytical system.

Lipid profile done using serum sample on the fully automatic analyzer by: a) total cholesterol estimated by enzymatic, CHOD/PAP method with cholesterol esterase, cholesterol oxidase and 4-aminoantipyrine, supplied by Roche Diagnostic Ltd.; b) triglyceride estimated by enzymatic, GPO/PAP method with glycerol phosphate oxidase and 4-aminoantipyrine, supplied by Roche Diagnostic Ltd.; c) high density lipoprotein estimated by enzymatic, CHOD/PAP method cholesterol esterase, cholesterol oxidase and N,N-bis (4-sulfobutyl)-m-toludine supplied by Roche Diagnostic Ltd.; d) low density lipo- 
protein estimated by enzymatic, CHOD/PAP method with cholesterol esterase, cholesterol oxidase and 4-aminoantipyrine, supplied by Roche Diagnostic Ltd.; e) very low density lipoprotein estimated by enzymatic, CHOD/PAP method, supplied by Roche Diagnostic Ltd.

Fasting blood sugar estimation was done on the fully automatic analyzer using the enzymatic assay kit, plasma as a sample.

Homocysteine assay in the plasma sample done by ELISA, using an enzymatic homocysteine assay manufactured by Bio-Quant, based on novel assay principle that assess the concentration of homocysteine in the sample which is indirectly proportional to the amount of NADH converted to $\mathrm{NAD}^{+}$(co-substrate conversion product).

hs-CRP has been done by high sensitivity enzyme immunoassay for quantitative determination of CRP in serum sample, manufacture by BioCheck, Inc. based on solid phase enzyme-linked immunosorbant assay that utilizes a unique monoclonal antibody directed against a distinct antigenic determinant on the CRP molecule.

Lipoprotien(a) in serum sample done by a latex enhanced immunoturbidimetric method using Lp(a) Diazyme's assay kit. Lp(a) present in the sample binds to the specific anti-Lp(a) antibody and causes agglutination, that can be measured optically at $700 \mathrm{~nm}$ and is proportional to amount of $\mathrm{Lp}(\mathrm{a})$ in the sample.

Blood parameters, fibrinogen, erythrocyte sedimentation rate (ESR) were measured having role in vascular biology and inflammation, fibrinogen estimated by highly sensitive two-site ELISA based on anti FIB antibody, horseradish peroxidase and TMB (tetra methyl benzidine) as chromogenic substrate with a risk of $>300 \mathrm{mg} / \mathrm{dl}$ value [29], supplied by Alpco Diagnostics. Blood parameter erythrocyte sedimentation rate (ESR) was estimated by blood cell counter having a normal range for male $-14 \mathrm{~mm} / \mathrm{h}$, female $-21 \mathrm{~mm} / \mathrm{h}$ [30].

Urine sample was analyzed for renal function parameter albumin excretion rate (AER) and creatinine clearance rate (Ccr), AER by using Esbach's albuminometer and Ccr by Jaffe reaction.

To ascertain the potential clinical usefulness of each putative risk marker we followed a prior analysis plan. Student ' $t$ ' test was applied to find out the significant difference between two groups. Pearson's correlation analysis was performed between homocysteine and inflammatory marker and between inflammatory markers and other risk factors for their positive or negative association in statistical evaluation. Multiple regression analysis was done for main determinants of homocysteine taken cardiovascular disease as the dependent variable. A $P$ value $<0.05$ were accepted as indicating a significant statistical analysis were performed using SPSS version 14.3 and the results represented as mean \pm SD.

\section{Results and Discussion}

Patients were divided in two groups, diabetic associated CVD as group II and without CVD as group I, on the basis of blood glucose or previous history of diabetes and angiographic findings. Baseline data are shown in Table 1. Diabetic subjects with CVD had higher triglyceride, very low density lipoprotein, low HDL-C and albumin excretion rate and from the inflammatory markers diabetic subjects with CVD had higher homocysteine, fibrinogen, hsCRP, erythrocyte sedimentation rate with $P<0.05$.

Homocysteine showed a strong positive and significant correlation with AER, triglyceride, haemoglobinA1c (HbA1c), while it was observed negatively correlated with Ccr, HDL-C $(P<0.05)$. The correlation coefficients between the variables were differing significantly among subjects with CVD and in those without CVD when analyzed separately.

In Table 2 we report correlation of inflammatory markers homocysteine, fibrinogen, hs-CRP, erythrocyte sedimentation rate, lipoprotein (a) with other routine CVD risk factors and it was found that homocysteine, fibrinogen, hs-CRP, Lp(a) are inversely related to Ccr and HDL-C, while ESR is negatively correlated with HDL-C and positively with creatinine clearance rate. We have found a significant positive correlation of homocysteine and albumin excretion rate $(r=0.900, P<0.01)$, triglyceride $(r=0.720, P<0.01)$, HbA1c $(r=0.765, P<0.01)$ and significant negative correlation of homocysteine with Ccr $(r=-0.870, P<0.01)$, HDL-C $(r=-0.626$, $P<0.01)$ in diabetic subjects with CVD.

We have found a significant positive correlation of homocysteine with other inflammatory marker as shown in Table 3. The results of univariate analysis suggest a role of homocysteine in CVD for further confirmation; we applied multivariate analysis as shown in Table 4, we have found homocysteine as a strong predictor of CVD, T value -4.130, $P<0.001$. CVD is more prevalent and progresses more rapidly in diabetics in comparison to normal subjects. In the present study, markers of inflammation were found to be significantly elevated in diabetic patients 
Table 1. Clinical characteristics and laboratory data of the patients with and without atherosclerotic vascular disease

\begin{tabular}{l|c|c}
\hline \multicolumn{1}{c|}{ Risk Factor } & $\begin{array}{c}\text { Subjects without vascular } \\
\text { disease (group I) }\end{array}$ & $\begin{array}{c}\text { Subjects with vascular } \\
\text { disease (group II) }\end{array}$ \\
\hline Age & $52.02 \pm 9.47$ & $61.32 \pm 10.19$ \\
Sex (M/F) & $4: 1$ & $4.5: 0.5$ \\
Body Mass Index (BMI) & $21.86 \pm 2.38$ & $25.43 \pm 3.45$ \\
Cholesterol, mg/dl & $165.26 \pm 22.84$ & $287.58 \pm 27.35$ \\
Triglyceride, mg/dl & $183.10 \pm 65.20$ & $278.86 \pm 46.87$ \\
HDL-C, mg/dl & $43.28 \pm 7.34$ & $28.44 \pm 9.02$ \\
LDL-C, mg/dl & $110.08 \pm 29.94$ & $166.36 \pm 23.26$ \\
VLDL-C, mg/dl & $34.74 \pm 9.14$ & $45.54 \pm 12.199$ \\
HbA1c, \% & $7.00 \pm 0.58$ & $9.17 \pm 0.97$ \\
ESR, ml/h & $17.98 \pm 1.23$ & $34.39 \pm 4.14$ \\
Ccr, ml/minx1.73 m ${ }^{2}$ & $79.01 \pm 4.50$ & $60.54 \pm 6.42$ \\
AER, mg/day & $49.73 \pm 17.08$ & $561.52 \pm 128.93$ \\
Lp(a), mg/dl & $23.52 \pm 5.06$ & $63 \pm 40.02$ \\
hs-CRP, mg/dl & $0.530 \pm 0.194$ & $1.32 \pm 1.45$ \\
Fibrinogen, mg/dl & $385.51 \pm 9.45$ & $461.63 \pm 14.171$ \\
Homocysteine, $\mu$ mol/l & $6.69 \pm 1.60$ & $16.48 \pm 1.15$ \\
\hline
\end{tabular}

The mean difference is significant statistically at the 0.05 level. HDL-C - high density cholesterol, LDL-C - low density cholesterol, VLDL-C - very low density cholesterol, HbA1c - haemoglobinA1c, ESR - erythrocyte sedimentation rate, $\mathrm{Ccr}$ - creatinine clearance, AER - albumin excretion rate, Lp(a) - lipoprotein(a), hs-CRP - high sensitivity C reactive protein, M-male \& F-female; $n=50, P<0.05$.

Table 2. Pearson's correlation coefficient between inflammatory markers, homocysteine level, and other cardiovascular risk factors

\begin{tabular}{l|c|c|c|c|c}
\hline $\begin{array}{c}\text { Risk Factor } \rightarrow \\
\text { Inflammatory } \\
\text { marker } \downarrow\end{array}$ & $\begin{array}{c}\text { Ccr (ml/ } \\
\left.\mathrm{mx} 1.73 / \mathrm{m}^{2}\right)\end{array}$ & AER (mg/day) & $\begin{array}{c}\text { Triglyceride } \\
(\mathrm{mg} / \mathrm{dl})\end{array}$ & HDL-C (mg/dl) & HbAlc (\%) \\
\hline Hcy, $\mu \mathrm{mol} / \mathrm{l}$ & $r=-0.870$ & $r=0.900$ & $r=0.720$ & $r=-0.626$ & $r=0.765$ \\
& $P<0.01$ & $P<0.01$ & $P<0.01$ & $P<0.01$ & $P<0.01$ \\
Fibrinogen, & $r=-0.806$ & $r=0.909$ & $r=0.623$ & $r=-0.643$ & $r=0.754$ \\
mg/dl & $P<0.01$ & $P<0.01$ & $P<0.01$ & $P<0.01$ & $P<0.01$ \\
hs-CRP, mg/dl & $r=-0.253$ & $r=0.376$ & $r=0.256$ & $r=-0.155$ & $r=0.264$ \\
& $P<0.05$ & $P<0.01$ & $P<0.01$ & & $P<0.01$ \\
Lp(a), mg/dl & $r=-0.492$ & $r=0.496$ & $r=0.382$ & $r=-0.394$ & $r=0.370$ \\
& $\mathrm{P}<0.01$ & $P<0.01$ & $P<0.01$ & $P<0.01$ & $P<0.01$ \\
ESR, ml/h & $r=0.792$ & $r=0.867$ & $r=0.596$ & $r=-0.655$ & $r=0.732$ \\
& $P<0.01$ & $P<0.01$ & $P<0.01$ & $P<0.01$ & $P<0.01$ \\
\hline
\end{tabular}

The mean difference is significant statistically at the 0.05 level and highly significant at 0.01 levels. Hcy - homocysteine, AER - albumin excretion rate, Lp(a) - lipoprotein (a), hs-CRP - high sensitivity C reactive protein. 
Ta ble 3. Pearson correlation coefficients between plasma homocysteine level and inflammation markers

\begin{tabular}{c|c|c|c|c}
\hline $\begin{array}{c}\text { Inflammatory } \\
\text { marker } \rightarrow\end{array}$ & Fibrinogen & hs-CRP & Lp(a) & ESR \\
\hline Homocysteine & $r=0.915$ & $r=0.360$ & $r=0.533$ & $r=0.899$ \\
& $P<0.01$ & $P<0.01$ & $P<0.01$ & $P<0.01$ \\
\hline
\end{tabular}

The mean difference is significant at the $P<0.05$ level and at $P<0.01$ is highly significant hs-CRP - high sensitivity $C$ reactive protein, $\mathrm{Lp}(\mathrm{a})$ - lipoprotein (a), ESR - erythrocyte sedimentation rate.

Table 4. Main determinants of homocysteine level based on multiple regressions analysis with cardiovascular disease as the dependant variable

\begin{tabular}{|c|c|c|c|c|c|c|c|}
\hline \multirow{2}{*}{ Risk Factor } & \multicolumn{2}{|c|}{$\begin{array}{l}\text { Unstandardized } \\
\text { coefficients }\end{array}$} & \multirow{2}{*}{$\begin{array}{c}\text { Standardized } \\
\text { coefficients } \\
\text { Beta }\end{array}$} & \multirow{2}{*}{$\mathrm{T}$} & \multirow{2}{*}{ Sig. } & \multicolumn{2}{|c|}{$95 \%$ CI for B } \\
\hline & B & Std Error & & & & $\begin{array}{l}\text { Lower } \\
\text { bound }\end{array}$ & $\begin{array}{l}\text { Upper } \\
\text { bound }\end{array}$ \\
\hline Age & -0.001 & 0.001 & -0.020 & -1.242 & 0.218 & -0.002 & 0.001 \\
\hline BMI & -0.001 & 0.003 & -0.010 & -0.549 & 0.585 & -0.006 & 0.004 \\
\hline T Cholesterol & -0.001 & 0.000 & -0.089 & -2.255 & 0.027 & -0.001 & 0.000 \\
\hline HDL-C & -0.001 & 0.001 & -0.019 & -0.902 & 0.370 & -0.003 & 0.001 \\
\hline LDL-C & 0.000 & 0.000 & -0.015 & -0.646 & 0.520 & -0.001 & 0.000 \\
\hline VLDL-C & -0.001 & 0.001 & -0.013 & -0.747 & 0.457 & -0.002 & 0.001 \\
\hline $\mathrm{TG}$ & 0.000 & 0.000 & 0.031 & 1.328 & 0.188 & 0.000 & 0.001 \\
\hline HbA1c & -0.056 & 0.013 & -0.153 & -4.200 & 0.000 & -0.083 & -0.030 \\
\hline Lp(a) & 0.000 & 0.000 & -0.002 & -1.372 & 0.174 & -0.001 & 0.000 \\
\hline Hs-CRP & -0.001 & -0.001 & -0.003 & -0.184 & 0.855 & -0.015 & 0.013 \\
\hline Ccr & 0.002 & 0.001 & 0.042 & 1.432 & 0.156 & -0.001 & 0.005 \\
\hline AER & 0.000 & 0.000 & -0.137 & -3.498 & 0.001 & 0.000 & 0.000 \\
\hline Fibrinogen & -0.003 & 0.001 & -0.235 & -5.762 & 0.000 & -0.004 & -0.002 \\
\hline ESR & -0.009 & -0.009 & -0.150 & -3.764 & 0.000 & -0.013 & -0.004 \\
\hline (Hсу) & -0.023 & 0.005 & -0.230 & -4.130 & 0.000 & -0.033 & -0.012 \\
\hline
\end{tabular}

HDL-C - high density cholesterol, LDL-C - low density cholesterol, VLDL-C - very low density cholesterol, HbA1c haemoglobin A1c, ESR - erythrocyte sedimentation rate, Ccr - creatinine clearance, AER - albumin excretion rate, Lp(a) - lipoprotein(a), hs-CRP - high sensitivity C reactive protein.

with CVD in compression to subjects without CVD. These findings indicate inflammatory activity in study subjects.

Homocysteine level was found to be elevated in patients with vascular disease and was proposed to contribute to atherosclerosis in patients with CVD, stroke and peripheral vascular disease, the pathogenesis behind is: homocysteine induced vascular pathologies including fragmentation of internal elastic lamina, disruption of elastic fibers, smooth muscle hyperplasia and arterial and venous thrombosis [31]. These findings suggest inflammatory ac- tivity and role of homocysteine as a risk factor in CVD [32].

Earlier studies on homocysteine reported differences in the level of homocysteine, ranging 13.9$20.1 \mu \mathrm{mol} / \mathrm{l}$ in person with CVD [33, 34] but we have found a mean homocysteine level 16.48 in CVD group II and 6.69 in group I. The homocysteine levels tend to be increased in the presence of other CVD risk factors like age, diabetes, obesity and abnormal lipid parameters and smoking.

Like homocysteine elevated fibrinogen, lipoprotein (a), ESR levels were also found in the present 
study, they also have a significant negative correlation with HDL-cholesterol level. It is possible that these inflammatory markers may impair the production or accelerate the catabolism of these lipoproteins that are protective against the atherosclerosis process [35]. It is also seen in the study of Stemme S. et al. in diabetics [36].

Inflammatory markers were shown to be closely related with microalbuminuria and other renal functions that are indicators of renal endothelial injury. However, it is not clear whether inflammation is the cause of nephropathy or inflammatory activity or it is elevated in response to nephropathy [37, 38].

Plasma homocysteine levels are affected directly by the renal functions due to its clearance by the kidney [39]. In the present study homocysteine is having negative significant correlation with Ccr and positive significant correlation with AER. Like homocysteine, fibrinogen, hs-CRP and Lp(a) were also in a significant negative correlation with Ccr.

Of the other inflammatory markers, hs-CRP is the acute phase protein, produced by the liver and marker of systemic inflammation, its elevation in blood may persist in chronic inflammatory conditions. Its production is mediated by interleukin- 6 (IL-6), Starling et al. in 2003 reported a positive inverse relationship between hs-CRP and Ccr [40]. This is further supported by studies of PW by de Winter R. J. et al. in atherosclerotic hypertensive patients [41]. Elevated fibrinogen with decreased Ccr suggests that defective coagulation system in the study subjects; this is supported by study of Cateha C et al. [42, 43]. Increased Lp(a) with decreased Ccr are associated with early impairment of renal function and are associated with greater prevalence of CVD, as supported by study in [44, 45].

In literature, both inflammation marker and homocysteine levels were investigated in diabetic patients, but there is no much data of studying their relationship with each other. In our study there is significant relationship found between inflammatory marker and homocysteine levels $(P<0.01)$.

Several recent overview analyses for both homocysteine [45] and lipoprotein (a) [46] had reported statistically significant relationship, according to the study of Eastern et al. [47] there is a significant association of elevated homocysteine and hs-CRP in stenoic coronary arteries. Another study conducted by Aso Y. et al. [48] reported a significant correlation of inflammatory marker hs-CRP, IL-6 and fibrinogen levels with elevated homocysteine levels.
There are some other studies which reported the relationship of homocysteine levels to inflammation in patients with CVD in elderly patients, suggesting a causal relationship between them $[49,50]$ but they have not taken GFR into the account, this is an important part of study and reflecting that the impairment of renal function is common in patients with prolonged diabetes and old age patients.

As the results of our study show, homocysteine levels have significant association with inflammatory markers and abnormal renal functions in a study of population of diabetics with CVD.

In conclusion, we may state that elevated homocysteine and abnormal renal function are involved in CVD and related complications, i.e. one associated with other and it is difficult to suggest which one initiate and propagate the other. Further study is needed in this direction, taking young patients with diabetes and CVD to understand the exact biochemical mechanism involving, and the role of Hyperhomocysteinemia.

\section{Acknowledgements}

I feel myself to be fortunate to work in the Department of Biochemistry \& Out Patient Department MGM Medical College associated hospital, Indore for this work. I would like to take the opportunity to express my sincere thanks to all participants of this study.

\section{СЕРЦЕВО-СУДИННІ \\ ЗАХВОРЮВАННЯ У ХВОРИХ НА ЦУКРОВИЙ ДІАБЕТ 2-ГО ТИПУ: ГОМОЦИСТЕЇН ЯК МАРКЕР ЗАПАЛЕННЯ}

\author{
Ashok Sahu', Trapti Gupta ${ }^{2}$, Arvind \\ Kavishwar $^{3}$, R. K. Singh ${ }^{4}$
}

${ }^{1}$ MGM Medical College Indore, Jabalpur, India; e-mail: asahu888@gmail.com; asahu888@yahoo.co.in; ${ }^{2}$ NSCB Medical College, Jabalpur, India; ${ }^{3}$ Regional Malaria Research Centre of Tribal (ICMR), Jabalpur, India; ${ }^{4}$ Chirayu Hospital, Bhopal, India

Вважається, що запалення відіграють певну роль у патогенезі серцево-судинних захворювань; вимірювання маркерів запалення дозволяє покращити оцінку ризику серцево-судинних захворювань (СС3). Гіпергомоцистеїнемія корелює 3 виникненням тромбів, інфарктів й інсультів, хоча неясно, чи є гіпергомоцистеїнемія 
незалежним чинником ризику для цих умов. $\mathrm{y}$ роботі досліджували роль гомоцистеїну у хворих на діабет із СС3 в Індії, штат Мадх'яПрадеш. Досліджували дві групи хворих на діабет (типу 2): група I $(n=50)-$ без CC3 і група II $(n=50)$ наявність СС3 доведена методом ангіографії. У сироватці крові вимірювали C-реактивний протеїн (YS-CRP), фібриноген i ліпопротеїн (a). Також вимірювали вміст гомоцистеїну, глюкози в плазмі, швидкість зсідання еритроцитів та концентрацію глікозильованого гемоглобіну. Рівень екскреції альбуміну і кліренс креатиніну вимірювали в сечі для оцінки роботи нирок. Показано, що рівні гомоцистеїну та інших маркерів запалення були значно підвищені в групі II $(n=50)$ в порівнянні з групою I. Спостерігали кореляцію між гіпергомоцистеїнемією та маркерами запалення в пацієнтів із порушеною функцією нирок. Дійшли висновку про те, що порушення функції нирок $є$ ключовим фактором, який впливає на рівень гомоцистеїну.

К л ю ч о в $\quad$ с ло в а: $\quad$ гомоцистеїн (HCY), С-реактивний протеїн (HS-CRP), ліпопротеїни (a), кліренс креатиніну, серцевосудинні захворювання, діабет 2-го типу, глікозильований гемоглобін.

\section{СЕРДЕЧНО-СОСУДИСТЫЕ ЗАБОЛЕВАНИЯ У БОЛЬНЫХ САХАРНЫМ ДИАБЕТОМ 2-ГО ТИПА: ГОМОЦИСТЕИН КАК МАРКЕР ВОСПАЛЕНИЯ}

\author{
Ashok Sahu', Trapti Gupta ${ }^{2}$, Arvind \\ Kavishwar ${ }^{3}$, R. K. Singh ${ }^{4}$
}

${ }^{1}$ MGM Medical College Indore, Jabalpur, India; e-mail: asahu888@gmail.com; asahu888@yahoo.co.in;

${ }^{2}$ NSCB Medical College, Jabalpur, India; ${ }^{3}$ Regional Malaria Research Centre of Tribal (ICMR), Jabalpur, India; ${ }^{4}$ Chirayu Hospital, Bhopal, India

Считается, что воспаление играет определенную роль в патогенезе сердечно-сосудистых заболеваний; измерение маркеров воспаления позволяет улучшить оценку риска сердечно-сосудистых заболеваний (СС3). Гипергомоцистеинемия коррелирует с возникновением тромбов, инфарктов и инсультов, хотя неясно, является ли гипергомоцистеинемия не- зависимым фактором риска для этих условий. В работе исследовали роль гомоцистеина у больных диабетом с СС3 в Индии, штат Мадхья-Прадеш. Исследовали две группы больных диабетом (тип 2): група I $(n=50)-$ без СС3 и група II $(n=50)$ - наличие CC3 доказано методом ангиографии. В сыворотке крови измеряли C-реактивный протеин (YS-CRP), фибриноген и липопротеин (a), а также уровень гомоцистеина, глюкозы в плазме, скорость оседания эритроцитов, концентрацию гликозилированного гемоглобина. Уровень экскреции альбумина и клиренс креатинина измеряли в моче для контроля работы почек. Показано, что уровни гомоцистеина и других маркеров воспаления были значительно повышены в группе II $(n=50)$ по сравнению с группой I. Наблюдали корреляцию гипергомоцистеинемии и воспалительных маркеров в группе пациентов с нарушенной функцией почек. Сделан вывод о том, что нарушение функции почек является ключевым фактором, который влияет на уровень гомоцистеина.

К л ю чев ы е с лов а: гомоцистеин (HCY), C-реактивный протеин (HS-CRP), липопротеины (а), клиренс креатинина, сердечно-сосудистые заболевания, диабет 2-го типа, гликозилированный гемоглобин.

\section{References}

1. Ridker PM, Stampfer MJ, Rifai N. Novel risk factors for systemic atherosclerosis: a comparison of C-reactive protein, fibrinogen, homocysteine, lipoprotein(a), and standard cholesterol screening as predictors of peripheral arterial disease. JAMA. 2001; 285(19): 24812485.

2. Elkind MS, Cheng J, Boden-Albala B, Rundek T, Thomas J, Chen H, Rabbani LE, Sacco RL. Tumor necrosis factor receptor levels are associated with carotid atherosclerosis. Stroke. 2002; 33(1): 31-37.

3. Papanicolaou DA, Wilder RL, Manolagas SC, Chrousos GP. The pathophysiologic roles of interleukin-6 in human disease. Ann Intern Med. 1998; 128(2): 127-137.

4. Klein RL, Hunter SJ, Jenkins AJ, Zheng D, Semler AJ, Clore J, Garvey WT; DCCT/ ECIC Study Group. Fibrinogen is a marker for nephropathy and peripheral vascular disease in type 1 diabetes: studies of plasma fibrinogen and 
fibrinogen gene polymorphism in the DCCT/ EDIC cohort. Diabetes Care. 2003; 26(5): 14391448.

5. Torbus-Lisiecka B, Bukowska H, Jastrzebska M, Chelstowski K, Honczarenko K, Naruszewicz M. Lp(a), homocysteine and a family history of early ischemic cerebral stroke. Nutr Metab Cardiovasc Dis. 2001; 11(Suppl 5): 52-59.

6. Stehouwer CD, Gall MA, Twisk JW, Knudsen E, Emeis JJ, Parving HH. Increased urinary albumin excretion, endothelial dysfunction, and chronic low-grade inflammation in type 2 diabetes: progressive, interrelated, and independently associated with risk of death. Diabetes. 2002; 51(4): 1157-1165.

7. Ceriello A, Taboga C, Giacomello R, Falleti E, De Stasio G, Motz E, Lizzio S, Gonano F, Bartoli E. Fibrinogen plasma levels as a marker of thrombin activation in diabetes. Diabetes. 1994; 43(3): 430-432.

8. Buysschaert M, Dramais AS, Wallemacq PE, Hermans MP. Hyperhomocysteinemia in type 2 diabetes: relationship to macroangiopathy, nephropathy, and insulin resistance. Diabetes Care. 2000; 23(12): 1816-1822.

9. Koning ABL, Werstuck GH, Zhou J, Austin RC. Hyperhomocysteinemia and its role in the development of atherosclerosis. Clin Biochem. 2003; 36(6): 431-441.

10. Abdella NA, Mojiminiyi OA, Akanji AO, Moussa MA. Associations of plasma homocysteine concentration in subjects with type 2 diabetes mellitus. Acta Diabetol. 2002; 39(4): 183-190.

11. Kanani PM, Sinkey CA, Browning RL, Allaman M, Knapp HR, Haynes WG. Role of oxidant stress in endothelial dysfunction produced by experimental hyperhomocyst(e) inemia in humans. Circulation. 1999; 100(11): 1161-1168.

12. Stühlinger MC, Tsao PS, Her JH, Kimoto M, Balint RF, Cooke JP. Homocysteine impairs the nitric oxide synthase pathway: role of asymmetric dimethylarginine. Circulation. 2001; 104(21): 2569-2575.

13. Majors A, EhrhartLA, PezackaEH. Homocysteine as a risk factor for vascular disease. Enhanced collagen production and accumulation by smooth muscle cells. Arterioscler Thromb Vasc Biol. 1997; 17(10): 2074-2081.
14. Al-Obaidi MK, Philippou H, Stubbs PJ, Adami A, Amersey R, Noble MM, Lane DA. Relationships between homocysteine, factor VIIa, and thrombin generation in acute coronary syndromes. Circulation. 2000; 101(4): 372-377.

15. Voutilainen S, Morrow JD, Roberts LJ 2nd, Alfthan G, Alho H, Nyyssönen K, Salonen JT. Enhanced in vivo lipid peroxidation at elevated plasma total homocysteine levels. Arterioscler Thromb Vasc Biol. 1999; 19(5): 1263-1266.

16. Chambers JC, Obeid OA, Refsum H, Ueland P, Hackett D, Hooper J, Turner RM, Thompson SG, Kooner JS. Plasma homocysteine concentrations and risk of coronary heart disease in UK Indian Asian and European men. Lancet. 2000; 355(9203): 523-527.

17. Nair KG, Nair SR, Ashavaid TF, Dalal JJ, Eghlim FF. Methylenetetrahydrofolate reductase gene mutation and hyperhomocysteinemia as a risk factor for coronary heart disease in the Indian population. $J$ Assoc Physicians India. 2002; 50 Suppl: 9-15.

18. Snehalatha C, Ramachandran A, Satyavani K, Sivasankari S, Sathyamurthy I, Viswanathan V. Plasma homocysteine concentration and coronary artery disease in Asian Indians. J Assoc Physicians India. 2002; 50: 1229-1231.

19. Deepa R, Velmurugan K, Saravanan G, Karkuzhali K, Dwarakanath V, Mohan V. Absence of association between serum homocysteine levels and coronary artery disease in south Indian males. Indian Heart J. 2001; 53(1): 44-47.

20. Laessig RH, Indriksons AA, Hassemer DJ, Paskey TA, Schwartz TH. Changes in serum chemical values as a result of prolonged contact with the clot. Am J Clin Pathol. 1976; 66(3): 598604.

21. Tsuchiya M, Asada A, Kasahara E, Sato EF, Shindo M, Inoue M. Smoking a single cigarette rapidly reduces combined concentrations of nitrate and nitrite and concentrations of antioxidants in plasma. Circulation. 2002; 105(10): 1155-1157.

22. WHO Expert Consultation. Appropriate body-mass index for Asian populations and its implications for policy and intervention strategies. Lancet. 2004; 363(9403): 157-163.

23. Chobanian AV, Bakris GL, Black HR, Cushman WC, Green LA, Izzo JL Jr, Jones DW, 
Materson BJ, Oparil S, Wright JT Jr, Roccella EJ. Seventh report of the joint national committee on prevention, detection, evaluation, and treatment of high blood pressure. Hypertension. 2003; 42(6): 1206-1252.

24. Definition, Diagnosis and classification of diabetes mellitus and its complications. World Health Organization 1999.

25. National Cholesterol Education Program National Heart, Lung, and Blood Institute National Institutes of Health NIH Publication No. 02-5215 September 2002.

26. Refsum H, Nurk E, Smith AD, Ueland PM, Gjesdal CG, Bjelland I, Tverdal A, Tell GS, Nygård $\mathrm{O}$, Vollset SE. The Hordaland Homocysteine Study: a community-based study of homocysteine, its determinants, and associations with disease. J Nutr. 2006; 136(6 Suppl): 1731S-1740S.

27. Ridker PM. High-sensitivity C-reactive protein: potential adjunct for global risk assessment in the primary prevention of cardiovascular disease. Circulation. 2001; 103(13): 1813-1818.

28. Dati F, Tate JR, Marcovina SM, Steinmetz A; International Federation of Clinical Chemistry and Laboratory Medicine; IFCC Working Group for Lipoprotein(a) Assay Standardization. First WHO/IFCC International Reference Reagent for Lipoprotein(a) for Immunoassay--Lp(a) SRM 2B. Clin Chem Lab Med. 2004; 42(6): 670-676.

29. Wetteland P, Røger M, Solberg HE, Iversen OH. Population-based erythrocyte sedimentation rates in 3910 subjectively healthy Norwegian adults. A statistical study based on men and women from the Oslo area. J Intern Med. 1996; 240(3): 125-131.

30. Whitton CM, Sands D, Hubbard AR, Gaffney PJ. A collaborative study to establish the 2nd International Standard for Fibrinogen, Plasma. Thromb Haemost. 2000; 84(2): 258-262.

31. Khajuria A, Houston DS. Induction of monocyte tissue factor expression by homocysteine: a possible mechanism for thrombosis. Blood. 2000; 96(3): 966-972.

32. Hoogeveen EK, Kostense PJ, Jakobs C, Dekker JM, Nijpels G, Heine RJ, Bouter LM, Stehouwer CD. Hyperhomocysteinemia increases risk of death, especially in type 2 diabetes : 5-year follow-up of the Hoorn Study. Circulation. 2000; 101(13): 1506-1511.
33. Yu HH, Joubran R, Asmi M, Law T, Spencer A, Jouma M, Rifai N. Agreement among four homocysteine assays and results in patients with coronary atherosclerosis and controls. Clin Chem. 2000; 46(2): 258-264.

34. Zylberstein DE, Bengtsson C, Björkelund C, Landaas S, Sundh V, Thelle D, Lissner L. Serum homocysteine in relation to mortality and morbidity from coronary heart disease: a 24year follow-up of the population study of women in Gothenburg. Circulation. 2004; 109(5): 601606.

35. Witztum JL, Berliner JA. Oxidized phospholipids and isoprostanes in atherosclerosis. Curr Opin Lipidol. 1998; 9(5): 441-448.

36. Stemme S, Faber B, Holm J, Wiklund O, Witztum JL, Hansson GK. T lymphocytes from human atherosclerotic plaques recognize oxidized low density lipoprotein. Proc Natl Acad Sci USA. 1995; 92(9): 3893-3897.

37. Festa A, D’Agostino R, Howard G, Mykkänen L, Tracy RP, Haffner SM. Inflammation and microalbuminuria in nondiabetic and type 2 diabetic subjects: The Insulin Resistance Atherosclerosis Study. Kidney Int. 2000; 58(4): 1703-1710.

38. Hommels MJ, van der Ven AJ, Kroon AA, Kessels AG, van Dieijen-Visser MP, van Engelshoven JA, Bruggeman CA, de Leeuw PW. C-reactive protein, atherosclerosis and kidney function in hypertensive patients. $J$ Hum Hypertens. 2005; 19(7): 521-526.

39. Malinow MR, Bostom AG, Krauss RM. Homocyst(e)ine, diet, and cardiovascular diseases: a statement for healthcare professionals from the Nutrition Committee, American Heart Association. Circulation. 1999; 99(1): 178-182.

40. Vigushin DM, Pepys MB, Hawkins PN. Metabolic and scintigraphic studies of radioiodinated human C-reactive protein in health and disease. J Clin Invest. 1993; 91(4): 1351-1357.

41. de Winter RJ, Fischer J, Bholasingh R, van Straalen JP, de Jong T, Tijssen JG, Sanders GT. $\mathrm{C}$-Reactive protein and cardiac troponin $\mathrm{T}$ in risk stratification: differences in optimal timing of tests early after the onset of chest pain. Clin Chem. 2000; 46(10): 1597-1603.

42. Vykoukal D, Davies MG. Vascular biology of metabolic syndrome. J Vasc Surg. 2011; 54(3): 819-831. 
43. Catena C, Zingaro L, Casaccio D, Sechi LA. Abnormalities of coagulation in hypertensive patients with reduced creatinine clearance. Am J Med. 2000; 109(7): 556-561.

44. Sechi LA, Zingaro L, Bartoli E. Increased serum lipoprotein(a) levels in patients with early renal failure. Ann Intern Med. 1999; 130(12): 10281029.

45. Sechi LA, Zingaro L, Catena C, Perin A, De Marchi s, Baroli E. Lipoprotien (a) and apolipoprotien (a) isoforms and proteinuria in patients with moderate renal failure. Clin $\mathrm{J} \mathrm{Am}$ Soc Nephrol. 1995; 6(3): 402.

46. Danesh J, Collins R, Peto R. Lipoprotein(a) and coronary heart disease. Meta-analysis of prospective studies. Circulation. 2000; 102(10): 1082-1085.

47. Yilmaz N, Ciçek HK, Celik A, Meram I, Kocabas R, Davutoglu V. Diagnostic value of homocysteine, C-reactive protein and bilirubin for coronary artery disease. East Mediterr Health J. 2007; 13(3): 522-535.

48. Aso Y, Yoshida N, Okumura K, Wakabayashi S, Matsutomo R, Takebayashi K, Inukai T. Coagulation and inflammation in overt diabetic nephropathy: association with hyperhomocysteinemia. Clin Chim Acta. 2004; 348(1-2): 139-145.

49. Gori AM, Corsi AM, Fedi S, Gazzini A, Sofi F, Bartali B, Bandinelli S, Gensini GF, Abbate R, Ferrucci L. A proinflammatory state is associated with hyperhomocysteinemia in the elderly. Am J Clin Nutr. 2005; 82(2): 335-341.

50. Jonasson T, Ohlin AK, Gottsäter A, Hultberg B, Ohlin H. Plasma homocysteine and markers for oxidative stress and inflammation in patients with coronary artery disease--a prospective randomized study of vitamin supplementation. Clin Chem Lab Med. 2005; 43(6): 628-634.

Received 23.11.2013 